\title{
Front Matter: Volume 10473
}

, "Front Matter: Volume 10473," Proc. SPIE 10473, Lasers in Dentistry XXIV, 1047301 (25 April 2018); doi: 10.1117/12.2315712

SPIE. Event: SPIE BiOS, 2018, San Francisco, California, United States 


\title{
PROGRESS IN BIOMEDICAL OPTICS AND IMAGING
}

\section{Lasers in Dentistry XXIV}

\author{
Peter Rechmann \\ Daniel Fried \\ Editors
}

28 January 2018

San Francisco, California, United States

Sponsored and Published by

SPIE 
The papers in this volume were part of the technical conference cited on the cover and title page. Papers were selected and subject to review by the editors and conference program committee. Some conference presentations may not be available for publication. Additional papers and presentation recordings may be available online in the SPIE Digital Library at SPIEDigitalLibrary.org.

The papers reflect the work and thoughts of the authors and are published herein as submitted. The publisher is not responsible for the validity of the information or for any outcomes resulting from reliance thereon.

Please use the following format to cite material from these proceedings:

Author(s), "Title of Paper," in Lasers in Dentistry XXIV, edited by Peter Rechmann, Daniel Fried, Proceedings of SPIE Vol. 10473 (SPIE, Bellingham, WA, 2018) Seven-digit Article CID Number.

ISSN: 1605-7422

ISSN: 1996-756X (electronic)

ISBN: 9781510614314

ISBN: 9781510614321 (electronic)

Published by

SPIE

P.O. Box 10, Bellingham, Washington 98227-0010 USA

Telephone +1 3606763290 (Pacific Time) · Fax +1 3606471445

SPIE.org

Copyright (C) 2018, Society of Photo-Optical Instrumentation Engineers.

Copying of material in this book for internal or personal use, or for the internal or personal use of specific clients, beyond the fair use provisions granted by the U.S. Copyright Law is authorized by SPIE subject to payment of copying fees. The Transactional Reporting Service base fee for this volume is $\$ 18.00$ per article (or portion thereof), which should be paid directly to the Copyright Clearance Center (CCC), 222 Rosewood Drive, Danvers, MA 01923. Payment may also be made electronically through CCC Online at copyright.com. Other copying for republication, resale, advertising or promotion, or any form of systematic or multiple reproduction of any material in this book is prohibited except with permission in writing from the publisher. The CCC fee code is 1605 $7422 / 18 / \$ 18.00$.

Printed in the United States of America.

Publication of record for individual papers is online in the SPIE Digital Library.

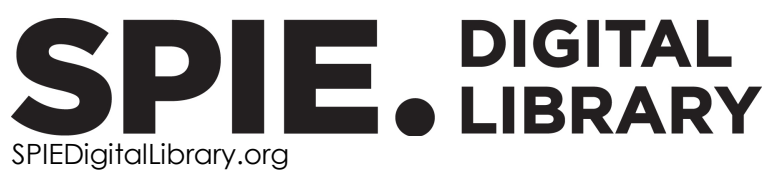

Paper Numbering: Proceedings of SPIE follow an e-First publication model. A unique citation identifier (CID) number is assigned to each article at the time of publication. Utilization of CIDs allows articles to be fully citable as soon as they are published online, and connects the same identifier to all online and print versions of the publication. SPIE uses a seven-digit CID article numbering system structured as follows:

- The first five digits correspond to the SPIE volume number.

- The last two digits indicate publication order within the volume using a Base 36 numbering system employing both numerals and letters. These two-number sets start with $00,01,02,03$, 04, 05, 06, 07, 08, 09, 0A, OB ... 0Z, followed by 10-1Z, 20-2Z, etc. The CID Number appears on each page of the manuscript. 


\title{
Contents
}

\author{
$\checkmark$ Authors \\ vii Conference Committee
}

\section{SESSION 1 CARIES LESION DETECTION}

1047302 Effect of bioglass on artificially induced enamel lesion around orthodontic brackets: OCT study [10473-1]

1047304 Deep learning classifier with optical coherence tomography images for early dental caries detection [10473-3]

1047305 Multispectral near-infrared reflectance and transillumination imaging of occlusal carious lesions: variations in lesion contrast with lesion depth [10473-4]

1047306 Laser speckle imaging for lesion detection on tooth [10473-5]

\section{SESSION 2 IMAGING OF HARD, SOFT TISSUE AND MICROBIAL PLAQUE}

1047308 Near-infrared dental imaging using scanning fiber endoscope [10473-7]

1047309 Photoacoustic imaging of teeth for dentine imaging and enamel characterization [10473-8]

10473 OA Optical measurement of acidification of human dental plaque in vitro [10473-9]

\section{SESSION 3 CARIES PREVENTION, REMINERALIZATION, ABLATION AND CERAMICS}

10473 OC Temperature variations in sintering ovens for metal ceramic dental prostheses: nondestructive assessment using OCT [10473-11]

10473 OD Lesion dehydration rate changes with the surface layer thickness during enamel remineralization [10473-12]

10473 OE Selective ablation of carious lesions using an integrated near-IR imaging system and a novel 9.3- $\mu \mathrm{m} \mathrm{CO} 2$ laser [10473-13]

\section{SESSION 4 BONE ABLATION, SOFT TISSUE TREATMENT AND MICROANGIOGRAPHY}

10473 OG Three-frequency Nd:YAG laser for dental treatment [10473-15]

10473 ol Ex vivo evaluation of super pulse diode laser system with smart temperature feedback for contact soft-tissue surgery [10473-17] 
$104730 \mathrm{~J}$ In vivo and ex vivo characterization of a novel Er fiber laser system for fractional treatment of soft oral tissues [10473-18]

\section{POSTER SESSION}

10473 OK Wavelength comparison for laser induced breakdown spectroscopy caries detection [10473-19]

1047300 Evaluation of enamel mineral loss around cavities prepared by the Er,Cr:YSGG laser and restored with different materials [10473-24]

$10473 \mathrm{OP}$ Temperature increasing in titanium implants using a high-intensity diode laser for periimplantitis decontamination [10473-25]

10473 OT Image-guided removal of interproximal lesions with a $\mathrm{CO}_{2}$ laser [10473-29]

10473 OU SWIR reflectance imaging of demineralization on the occlusal surfaces of teeth beyond $1700 \mathrm{~nm}[10473-30]$ 


\section{Authors}

Numbers in the index correspond to the last two digits of the seven-digit citation identifier (CID) article numbering system used in Proceedings of SPIE. The first five digits reflect the volume number. Base 36 numbering is employed for the last two digits and indicates the order of articles within the volume. Numbers start with 00, 01, 02, 03, 04, 05, 06, 07, 08, 09, OA, OB...0Z, followed by 10-12, 20-2Z, etc.

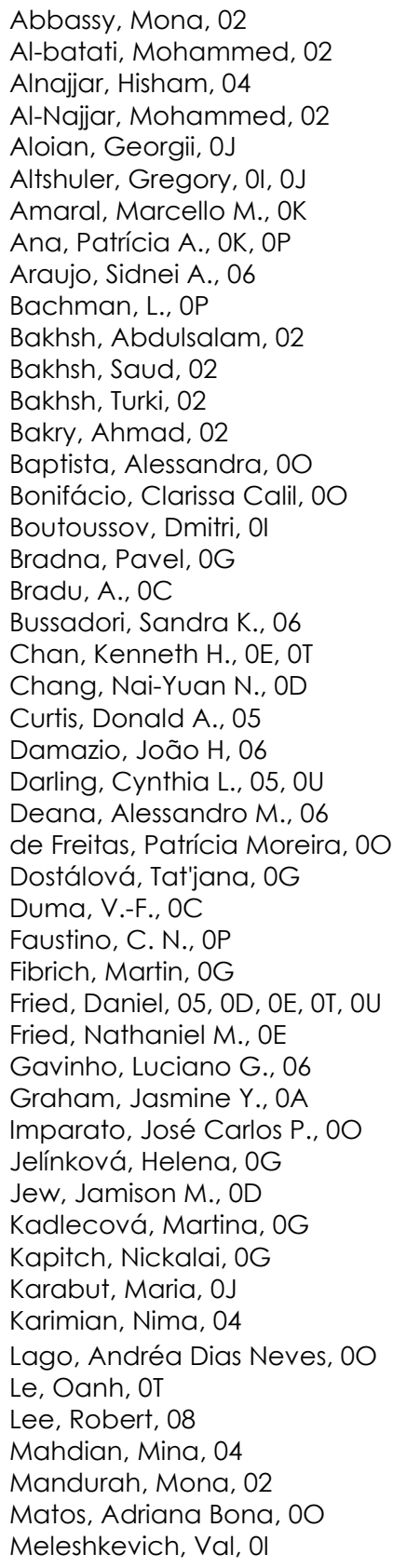

\author{
Mendes, Fausto Medeiros, 00 \\ Mukhtar, Mona, 02 \\ Navarro, Ricardo Scarparo, 00 \\ Negrutiu, M. L., OC \\ Nejezchleb, Karel, OG \\ Nelson, Leonard Y., OA \\ Němec, Michal, OG \\ $\mathrm{Ng}$, Chung, OU \\ Ngo, Albert, OT \\ Núñez, Sílvia Cristina, 0K, 00 \\ Olivan, Silvia R. G., 06 \\ Perchuk, Igor, 0 I \\ Periyasamy, Vijitha, 09 \\ Pinto, Marcelo M., 06 \\ Podoleanu, A. Gh., OC \\ Pramanik, Manojit, 09 \\ Prates, Renato A., 06 \\ Raele, Marcus P., OK \\ Rangaraj, Mani, 09 \\ Ryabova, Valentina, 0J \\ Sadr, Alireza, 08 \\ Salehi, Hassan S., 04 \\ Seibel, Eric J., 08, 0A \\ Sfalcin, Ravana A., 06 \\ Shatilova, Ksenia, OJ \\ Silva, João V. P., 06 \\ Simon, Jacob C., 05, OT, OU \\ Sinescu, C., OC \\ Škoda, Václav, OG \\ Šulc, Jan, OG \\ Tadinada, Aditya, 04 \\ Topala, F. I., OC \\ Vybornov, Alexander, 01 \\ Yaroslavsky, llya, Ol, OJ \\ Zamataro, Claudia B., OK \\ Zezell, Denise M., OK \\ Zhou, Yaxuan, 08
}


Proc. of SPIE Vol. 10473 1047301-6

Downloaded From: https://www.spiedigitallibrary.org/conference-proceedings-of-spie on 26 Apr 2023 Terms of Use: https://www.spiedigitallibrary.org/terms-of-use 


\title{
Conference Committee
}

\author{
Symposium Chairs
}

James G. Fujimoto, Massachusetts Institute of Technology

(United States)

R. Rox Anderson, Wellman Center for Photomedicine, Massachusetts

General Hospital (United States) and Harvard Medical School

(United States)

Program Track Chair

Brian Jet-Fei Wong, Beckman Laser Institute and Medical Clinic (United States)

Conference Chairs

Peter Rechmann, University of California, San Francisco (United States)

Daniel Fried, University of California, San Francisco (United States)

Conference Program Committee

Gregory B. Altshuler, IPG Medical Corporation (United States)

Tatjána Dostálová, Charles University in Prague (Czech Republic)

Thomas Ertl, Universität Stuttgart (Germany)

David M. Harris, Bio-Medical Consultants, Inc. (United States)

Jörg Meister, Universitätsklinikum Bonn (Germany)

Eric J. Seibel, University of Washington (United States)

\section{Session Chairs}

1 Caries Lesion Detection

Peter Rechmann, University of California, San Francisco

(United States)

2 Imaging of Hard, Soft Tissue and Microbial Plaque

Daniel Fried, University of California, San Francisco (United States) 
3 Caries Prevention, Remineralization, Ablation and Ceramics

Peter Rechmann, University of California, San Francisco

(United States)

4 Bone Ablation, Soft Tissue Treatment and Microangiography

Daniel Fried, University of California, San Francisco (United States) 